(C) 2013

Гончаренко О. М., аспірант*

Харківська державна зооветеринарна академія

\title{
ПЕРСПЕКТИВИ ВИКОРИСТАННЯ ТРЕОНІНУ В ГОДІВЛІ ПЛЕМІННИХ КУРЕЙ ВІТЧИЗНЯНОЇ СЕЛЕКЦЇ̈
}

\author{
Рецензент - доктор сільськогосподарських наук, ил.-кор. НААНУ В. М. Кандиба
}

\begin{abstract}
Введення в пшенично-кукурудзяно-соєвий комбікорм у період вирощування ремонтного молодняку (18-23 тижні) і утримання племінних курей (24-51 тиждень) L-треоніну до рівня 0,60 i 0,63\% достовірно збільшує: живу масу - на 5,4\%, яйценосність - на 5,5\%, заплідненість яєиь - на 1,1\%, вивід курчат - на 2,4\%, кількість інкубаційних яєиь - на 6,7\% $і$ зменшує витрати корму на 10 інкубаційних яєць на 6,6\%. У разі використання понад норму треоніну для племінних курей в яйці підвищилась як сума амінокислот (замінних $і$ незамінних), так $і$ концентрація треоніну - на 6,4 $i$ $12,1 \%$, по відношенню до контролю, щзо поглиблює положення про виробництво продуктів харчування з функиіональними властивостями.
\end{abstract}

Ключові слова: комбікорм, треонін, племінні кури, відтворювальні якості, амінокислоти.

Постановка проблеми. Підвищення рентабельності виробництва яєць істотно залежить від якості курчат. Для підвищення якості молодняку необхідно дотримуватись усіх елементів технології його вирощування й утримання дорослої птиці $[1,4]$.

Нині використовується чимало способів підвищення яйценоскості й плодючості племінних курей, серед яких, зокрема, балансування рецептів комбікормів із низьким рівнем тваринного протеїну за рахунок незамінних амінокислот (лізину, метіоніну, треоніну і триптофану) є досить актуальним [7].

Аналіз останніх досліджень i публікацій, у яких започатковано розв'язання проблеми. Треонін - друга лімітуюча амінокислота у більшості рослинних раціонів, заснованих на ячмені, пшениці, горосі і соєвому шроті. Доведено, що рівень водорозчинної фракції клітковини, яка міститься в раціоні, впливає на використання треоніну і лізину для виробництва протеїну тіла. У разі збільшення рівня пектину відкладення протеїну значно знижується в раціонах, дефіцитних за треоніном [5]. Встановлено, що за дефіциту треоніну в кормі знижується ефективність вико- ристання вільних амінокислот [6].

Біологічна роль треоніну в організмі складна й різноманітна: він регулює обмін білків, жирів $\mathrm{i}$ вуглеводів; бере участь у відкладенні жиру в печінці і черевній порожнині; покращує резистентність організму; підтримує роботу шлунковокишкового тракту шляхом захисту мукози від протеаз, бере участь у процесах метаболізму i засвоєння; сприяє утворенню колагену, який потрібний для нормального росту молодняку. Під дією ферменту альдолази треонін перетворюється на гліцин і оцтовий альдегід. За дезамінування від треоніну відщеплюється молекула води i утворюється альфа-кетомасляна кислота і аміак. Треонін може впливати на потребу птиці в лізині і метіоніні. Підвищений вміст треоніну в раціоні призводить до посилення утилізації лізину. Надлишок метіоніну в раціоні сприяє збільшенню активності дегідратази треоніну в печінці й тим самим обумовлює підвищення потреби в треоніні [12].

Встановлено, що кури засвоюють більше лізину на $10-15 \%$, сірковмісних амінокислот - на 8-12\% із комбікормів, у складі яких наявні тваринні білки, ніж із рослинних. Отже, за відсутності або низького рівня в комбікормах протеїну тваринного походження норми лізину, метіоніну, триптофану і треоніну доцільно збільшувати на $10 \%$ [11].

Оптимальна доза введення синтетичного треоніну в комбікорми може бути критичним чинником розвитку й функціонування кишковика, передусім у разі зміни складу комбікорму, зниженому споживанні корму під час стресів і за транспортування, відновлення після хвороби [10].

У літературі зустрічаються поодинокі відомості про вплив тривалого згодовування треоніну в рослинних комбікормах на ріст $\mathrm{i}$ розвиток ремонтного молодняку, продуктивність і відтворювальні якості племінних курей, починаючи 3 18- до 51-тижневого віку.

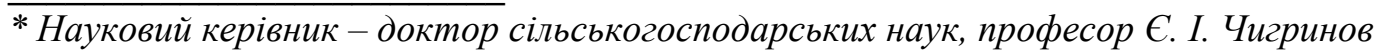




\section{СТОРІНКА МОЛОДОГО ВЧЕНОГО}

Метою досліджень було підвищити ефективність використання пшенично-кукурудзяносоєвих комбікормів для ремонтного молодняку і племінних курей полтавської глинистої породи за рахунок введення різного рівня треоніну.

Для досягнення поставленої мети ми ставили наступні завдання досліджень:

- вивчити вплив різного рівня синтетичного треоніну на зоотехнічні показники вирощування ремонтного молодняку та утримання племінних курей;

- вивчити міру використання організмом піддослідної птиці амінокислот із комбікормів та наступне дослідження якості інкубаційних яєць;

- експериментально обгрунтувати введення оптимальних доз треоніну в пшеничнокукурудзяно-соєві комбікорми.

Матеріали і методи досліджень. Науковогосподарський дослід проводився в 2009 році (з грудня по серпень) у дослідному господарстві «Борки» ІП НААНУ Харківській області. 3 добового до 17-тижневого віку курчата отримували комбікорм із різним рівнем треоніну. За принципом аналогів було сформовано три групи (по 200 голів) 18-тижневих ремонтних курочок полтавської глинистої породи. Птицю розміщували в клітинній батареї ОБН-4. Період яйцекладки становив 7 місяців. У досліді визначали оптимальний рівень треоніну $(0,53-$ 0,56, 0,56-0,60 і 0,60-0,63 \%) у комбікормі [9].

Із 18- до 51-тижневого віку курочкам першої групи згодовували повнораціонні пшеничнокукурудзяно-соєві комбікорми із вмістом
6,4-6,5 \% тваринних кормів $(8,1-11,0$ \% від протеїну). Птиця другої і третьої дослідних груп отримувала такий же комбікорм, але $з$ додаванням L-треоніну (98 \% фірми «Аджиномото») понад існуючу норму в кількості 0,03-0,04 і 0,07 \% відповідно (до рівня 0,56-0,60 і 0,60-0,63\%).

Під час експерименту враховували споживання і витрати комбікорму, збереження, однорідність птиці за живою вагою, продуктивні й відтворювальні якості, амінокислотний склад яєць. Концентрацію амінокислот визначали на амінокислотному аналізаторі Т-339 [3, 7].

Параметри мікроклімату і світловий режим відповідали нормативам ВНТП-АПК-04.05 [3].

Результати досліджень. Основним показником, що характеризує якість годівлі і найважливішим показником ефективності використання комбікормів, є яєчна продуктивність.

Результати продуктивності птиці представлені в табл. 1.

Різниця в живій масі ремонтних курочок (1-17 тижнів) змінювалася залежно від рівня треоніну. Введення треоніну в пшенично-кукурудзяносоєві комбікорми для племінних курей у продуктивний період сприяло збільшенню живої маси на $0,07-0,11$ кг. Жива маса в третій групі в $17-$ i 51-тижневому віці була високо достовірною $(\mathrm{P}<0,01$ і $\mathrm{P}<0,001)$ порівняно 3 іншими групами. Від курей другої і третьої дослідних груп було отримано на 0,4 і 6,7 яйця більше $(114,8$ і 121,1), ніж у контрольній (114,4 яєць). У розрахунку яйценоскості на початкову несучку спостерігалась аналогічна тенденція.

\section{1. Продуктивність курей}

\begin{tabular}{|c|c|c|c|}
\hline \multirow{2}{*}{ Показник } & \multicolumn{3}{|c|}{ Група } \\
\cline { 2 - 4 } & 1 (контроль) & 2 & 3 \\
\hline Жива маса, кг & \multicolumn{3}{|c|}{} \\
\hline 17 тижнів & $1,77 \pm 0,01$ & $1,81 \pm 0,009$ & $1,85 \pm 0,009^{* *}$ \\
\hline 51 тиждень & $1,93 \pm 0,011$ & $2,00 \pm 0,011$ & $2,04 \pm 0,011^{* * *}$ \\
\hline Яйценоскість, шт. & \multicolumn{3}{|c|}{121,1} \\
\hline на середню несучку, шт. & 114,4 & 114,8 & 119,2 \\
\hline на початкову несучку, шт. & 110,4 & 111,9 & $59,7 \pm 0,17$ \\
\hline Середня маса яєць, г & $59,0 \pm 0,18$ & $59,6 \pm 0,18$ & 4,19 \\
\hline $\begin{array}{c}\text { Витрати корму за період вирощування } \\
\text { (18-23 тижні), кг/гол. }\end{array}$ & 4,19 & 4,19 & 22,54 \\
\hline $\begin{array}{c}\text { Витрати корму за періодутримання } \\
\text { (24-51 тижня), кг/гол. }\end{array}$ & 22,54 & 22,54 & 1,97 \\
\hline $\begin{array}{c}\text { Витрати корму на 10 інкубаційних } \\
\text { яєць, кг }\end{array}$ & 2,11 & 2,04 & 97,0 \\
\hline Збереженість, \% & 93,5 & 95,0 & \\
\hline
\end{tabular}

Примітка: * - $\mathrm{P}<0,05 ; * *-\mathrm{P}<0,01 ; * * *-\mathrm{P}<0,001$ 
СТОРІНКА МОЛОДОГО ВЧЕНОГО

\section{2. Динаміка маси яєць (2)}

\begin{tabular}{|c|c|c|c|}
\hline \multirow{2}{*}{ Місяць яйценоскості } & \multicolumn{3}{|c|}{ Група } \\
\cline { 2 - 4 } & 1 (контроль) & 2 & 3 \\
\hline 1 & $51,11 \pm 0,22$ & $51,15 \pm 0,22$ & $51,16 \pm 0,21$ \\
\hline 2 & $55,26 \pm 0,19$ & $55,34 \pm 0,18$ & $55,66 \pm 0,18$ \\
\hline 3 & $57,73 \pm 0,18$ & $59,10 \pm 0,18$ & $58,90 \pm 0,16$ \\
\hline 4 & $60,18 \pm 0,16$ & $60,72 \pm 0,18$ & $60,77 \pm 0,16$ \\
\hline 5 & $61,29 \pm 0,18$ & $62,66 \pm 0,16$ & $62,78 \pm 0,16$ \\
\hline 6 & $63,35 \pm 0,16$ & $64,05 \pm 0,18$ & $64,03 \pm 0,16$ \\
\hline 7 & $64,03 \pm 0,18$ & $64,35 \pm 0,17$ & $64,57 \pm 0,17$ \\
\hline У середньому & $59,00 \pm 0,18$ & $59,60 \pm 0,18$ & $59,70 \pm 0,17$ \\
\hline
\end{tabular}

3. Динаміка витрат кормів на 10 яєць (кг)

\begin{tabular}{|c|c|c|c|}
\hline \multirow{2}{*}{ Місяць яйценоскості } & \multicolumn{3}{|c|}{ Група } \\
\cline { 2 - 4 } & 1 (контроль) & 2 & 3 \\
\hline 1 & 6,36 & 6,84 & 5,47 \\
\hline 2 & 1,98 & 2,07 & 1,98 \\
\hline 3 & 1,70 & 1,65 & 1,64 \\
\hline 4 & 1,77 & 1,96 & 1,50 \\
\hline 5 & 1,61 & 1,59 & 1,57 \\
\hline 6 & 1,69 & 1,62 & 1,65 \\
\hline 7 & 1,75 & 1,71 & 1,78 \\
\hline 3а 7 місяців & 1,97 & 1,96 & 1,86 \\
\hline
\end{tabular}

4. Відтворювальні якості курей

\begin{tabular}{|c|c|c|c|}
\hline \multirow{2}{*}{ Показники } & \multicolumn{3}{|c|}{ Група } \\
\cline { 2 - 4 } & 1 (контроль) & 2 & 3 \\
\hline Інкубаційних яєць, шт. & 106,6 & 110,3 & 114,2 \\
\hline Заплідненість яєць, \% & 93,2 & 96,1 & 94,3 \\
\hline Виводимість яєць, \% & 90,8 & 89,6 & 91,1 \\
\hline Вивід курчат, \% & 84,5 & 86,1 & 86,9 \\
\hline Отримано курчат, гол. & 97,0 & 99,0 & 104,0 \\
\hline
\end{tabular}

У другій і третій дослідних групах була вища збереженість птиці, ніж у контрольній групі, на 1,5-3,5 \% більше $(95,0-97,0 \%)$.

У досліді встановлено незначне збільшення маси яєць (із 59,0 г до 59,6-59,7 г) і зниження витрат корму на 10 інкубаційних яєць на 0,07 i 0,14 кг (табл. 2 і 3 ).

Маса яєць у кінці досліду в другій і третій групах склала 3,2 \% від живої маси курей порівняно 3 контролем (3,3\%). Маса яєць суттєво збільшилася за перші 3 місяці продуктивності (на 6,62-7,95 г) порівняно з наступними чотирма місяцями (3,63-3,85 г).

Найбільші витрати корму на 10 яєць були на першому місяці продуктивності (5,47-6,84 кг). $\mathrm{У}$ наступні місяці витрати корму зменшувалися до рівня 1,5 кг (на піку яйцекладки) в третій групі і поступово збільшувались у післяпіковому періоді (до 1,97 кг у контрольній групі).

Основним завданням в утриманні племінних курей $є$ отримання максимальної кількості інкубаційних яєць високої якості. Це досягається передусім годівлею ремонтного молодняку і курей батьківського стада залежно від віку та умов утримання.

Результати досліджень інкубаційних якостей яєць представлені в табл. 4.

Аналіз даних табл. 4 показав, що вищий вихід інкубаційних яєць був у курей другої і третьої груп (86,1 і 86,9 \%), а нижчий - у курей першої групи $(84,5 \%)$. Після 51-тижневого періоду споживання комбікорму, до складу якого були включені оптимальні дози треоніну, яйценоскість другої і третьої дослідних груп перевищувала контроль, відповідно, на 0,3 і 5,8 \%, заплідненість яєць - на 2,9 і 1,1 \%, вивід молодняку від закладених яєць - на 1,6 і 2,4 \%, кількість інкубаційних яєць - на 3,4 і 6,7\%, кількість отриманих курчат на 2 та $6,7 \%$ і виводимість яєць у третій групі - на $0,3 \%$. 
СТОРІНКА МОЛОДОГО ВЧЕНОГО

5. Амінокислотний склад курячих яєць (цілісних), г/100 2

\begin{tabular}{|c|c|c|c|}
\hline \multirow{2}{*}{ Показники } & \multicolumn{3}{|c|}{ Група } \\
\cline { 2 - 4 } & 1 (контроль) & 2 & 3 \\
\hline Вода, \% & $\mathbf{7 4 , 1 8}$ & $\mathbf{7 3 , 4 5}$ & $\mathbf{7 3 , 9 6}$ \\
\hline Сирий протеїн, \% & $\mathbf{1 2 , 7 5}$ & $\mathbf{1 2 , 7 3}$ & $\mathbf{1 2 , 8 1}$ \\
\hline Незамінні амінокислоти: & $\mathbf{4 , 9 6}$ & $\mathbf{4 , 9 5}$ & $0, \mathbf{9 6}$ \\
\hline Валін & 0,66 & 0,68 & 0,58 \\
\hline Ізолейцин & 0,59 & 0,56 & 1,14 \\
\hline Лейцин & 1,14 & 1,12 & 0,92 \\
\hline Лізин & 0,88 & 0,90 & 0,43 \\
\hline Метіонін & 0,43 & 0,41 & 0,66 \\
\hline Треонін & 0,58 & 0,62 & 0,70 \\
\hline Фенілаланін & 0,68 & 0,66 & $\mathbf{7 , 3 9}$ \\
\hline Замінні амінокислоти: & $\mathbf{7 , 1 3}$ & $\mathbf{7 , 2 9}$ & 0,83 \\
\hline Аланін & 0,82 & 0,78 & 0,73 \\
\hline Аргінін & 0,69 & 0,67 & 1,20 \\
\hline Аспарагінова кислота & 1,19 & 1,23 & 0,32 \\
\hline Гістидін & 0,32 & 0,33 & 0,40 \\
\hline Гліцин & 0,39 & 0,42 & 1,73 \\
\hline Глутамінова кислота & 1,67 & 1,72 & 0,37 \\
\hline Пролін & 0,35 & 0,36 & 0,94 \\
\hline Серин & 0,86 & 0,96 & 0,54 \\
\hline Тирозин & 0,53 & 0,49 & 0,33 \\
\hline Цистин & 0,31 & 0,33 & $\mathbf{1 2 , 5 0}$ \\
\hline Разом амінокислот & $\mathbf{1 2 , 0 9}$ & $\mathbf{1 2 , 2 4}$ & \\
\hline
\end{tabular}

Введення вказаних доз треоніну не впливає негативно на відтворювальну здатність, збереженість і продуктивність птиці, даючи змогу отримувати інкубаційні яйця високої якості [2].

Витрати треоніну на одну несучку в третій групі за дослід (238 діб) склали 22,3 грама. Споживання вказаної кількості треоніну дозволило збільшити кількість інкубаційних яєць на 8 штук, знизивши при цьому витрати комбікорму на 140 г, а на тисячу яєць - на 14 кг.

Дослідження показали, що найбільша інтенсивність яйценоскості $(61,8 \%)$ спостерігалася в третій групі курей, які споживали комбікорм, що містить 0,60-0,63 \% треоніну. Слід зауважити, що найвища інтенсивність $(73,2 \%)$ яйценоскості в третій групі спостерігалася на п'ятому місяці яйцекладки, після чого вона в усіх групах поступово знижувалася. Проте темп зниження був найнижчим у другій групі. За четвертий, п'ятий, шостий і сьомий місяці від курей третьої групи було отримано 80 яєць. Вміст незамінних амінокислот в яйці представлений в табл. 5. Аналіз іiі даних показав, що за використання понад норму треоніну для племінних курей в яйці підвищилася сума амінокислот (замінних i незамінних). Концентрація треоніну була більшою, ніж у контролі, на 6,4 і 12,1 \%, що підтверджує положення про виробництво продуктів харчування з функціональними властивостями.

\section{Висновки:}

1. Біологічну ефективність пшенично-кукурудзяно-соєвого комбікорму можна достовірно підвищити за рахунок введення в його склад оптимального рівня L-треоніну вище існуючої норми для племінних курей на 0,03-0,04 і 0,07 \%, що збільшує живу масу на 70 і 110 г, яйценоскість - на 0,3 i 5,8 \%, заплідненість яєць - на 2,9 і 1,1 \%, вивід молодняку від закладених яєць - на 1,6 і 2,4 \%, кількості інкубаційних яєць - на 3,4 та 7,1 \% і вихід курчат - на 2 i 7 голів, збереженість птиці - на 1,5 i $3,5 \%$, знижує витрати корму на тисячу інкубаційних яєць - на 7 і 14 кг. Витрати треоніну на одну несучку за дослід становила 11,2 і 22,3 грамів.

2. Підвищення нормування треоніну до вказаного рівня не впливає негативно на амінокислотний склад курячих яєць.

3. Наукова новизна отриманих результатів підтверджена декларативним патентом України на корисну модель «Спосіб підвищення відтворювальних якостей племінних курей» № 66948 МПК (2011.01) A23К 1/00 (25.01.2012, Бюл. № 2) [8]. 


\section{БІБЛІОГРАФІЯ}

1. Архипов А. В. Протеиновое питание птицы / А. В. Архипов, Л. В. Торопова. - М. : Колос, 1998. - 175 c.

2. Бекер $B$. Ф. Биологическая оценка кормового препарата треонина, полученного методом микробиологического синтеза / В. Ф. Бекер, С. В. Васильева, Р. Ю. Краузе [и др.] // Физиология процессов всасывания у животных. - Рига : Зинатие, 1986. - C. 58-66.

3. Відомчі норми технологічного проектування. Підприемства птахівництва / ВНТП-АПК-04.05 / Міністерство аграрної політики України (Мінагрополітики України). - К., 2005. - 90 с.

4. Глєбова Ю. А. Взаємодійний вплив середовища і генотипу на відтворну здатність яєчних курей / Ю. А. Глєбова // Сучасне птахівництво. - № 11-12 (96-97), листопад - грудень 2010. - С. 21-23.

5. Глєбова Ю. А. Годівля - фактор адаптаційної реакції яєчних курей / Ю. А. Глєбова // Сучасне птахівництво, №7-8 (68-69), 2008. - С. 19-28.

6. Ібатуллін I. I. Триптофан у комбікормах для курей-несучок / I. І. Ібатуллін, М. Я. Кривенок, Ю. О. Панасенко, В. Г. Добрівський // Сучасне птахівництво. - № 11-12 (96-97), листопад грудень 2010. - С. 39-40.

7. Лагодюк П. 3. Обмен веществ в организме свиней и птицы и уровень продуктивного действия корма в зависимости от аминокислотного состава рациона / П. З. Лагодюк, В. С. Скварук, Я. И. Слабицкий // Физиолого-биохимические и генетические основы повышения эффективности использования кормов в животноводстве : Зб. наук. праць ВНИИФБСХЖ. - Боровск, 1973. C. $158-159$.

8. Патент на корисну модель № 66948 / Україна, МПК 2011.01 А01К 33/00 А23К 1/00. Спосіб підвищення відтворювальних якостей племінних курей [Текст] / М. М. Лемешева, О. М. Гончаренко (Україна); заявник i правовласник Харківська державна зооветеринарна академія. № u 201108129 заявк. 29.06.2011 ; опубл. 25.01.2012, Бюл. № 2. $-10 \mathrm{c}$.

9. Теременко O. В. Рекомендації з нормування годівлі сільськогосподарської птиці / [Н. І. Братишко, О. В. Притуленко, М. М. Лемешева та ін.] під ред. О. В. Терещенка. - [3-є вид.] / ІП НААН. Бірки : НТМТ, 2010. $-88 \mathrm{c}$.

10. Чорна В. М. Ефективність застосування препарату треоніну мікробіологічного синтезу при зниженні рівня протеїну в комбікормах для бройлерів / В. М. Чорна, С. А. Водолажченко // Птахівництво. - Вип. 44. - Х., 1992. - С. 39-42.

11. Wormser E. H., Pardee A. B. Regulation of threonine biosynthesis in Escherichia coli, Arch. Biochim. Biophys., № 78, 1958. - P. 416-432.

12. Tesseraud S., Everaert N., Boussaid-Om Ezzine S., Collin A., Metayer-Coustard S. and Berri C. Manipulating tissue metabolism by amino acids. World's Poultry Science Journal, Vol. 67, June 2011. - P. 382-385. 